\title{
DISTRIBUSI DAN KELIMPAHAN LARVA IKAN DI KAWASAN PERAIRAN DESA MANGUNHARJO KECAMATAN TUGU KOTA SEMARANG
}

\author{
Distribution and Abundance of Larvae in the Waters Area of Mangunharjo Village, Tugu, Semarang City \\ Handika Wahyu Viyoga, Anhar Solichin*), Nurul Latifah \\ Program Studi Manajemen Sumberdaya Perairan, Departemen Sumberdaya Akuatik \\ Fakultas Perikanan dan Ilmu Kelautan Universitas Diponegoro \\ Jl. Prof. Soedarto, SH, Tembalang, Semarang, Jawa Tengah - 50275, Telp/Fax. +6224 7474698 \\ Email : handikaviyoga@gmail.com
}

\begin{abstract}
ABSTRAK
Distribusi dan kelimpahan larva ikan sangat bergantung dengan kondisi perairan di dalamnya. Kawasan perairan Desa Mangunharjo merupakan daerah yang unik karena memiliki tiga ekosistem yang berbeda yaitu ekosistem pantai, ekosistem muara, dan ekosistem mangrove. Penelitian ini bertujuan untuk mengetahui pola distribusi dan kelimpahan larva ikan pada tiga ekosistem yang berbeda di kawasan perairan Desa Mangunharjo. Penelitian dilaksanakan pada bulan Juli-Agustus 2017. Metode penelitian yang digunakan adalah survei dengan penentuan titik sampling secara systematic random. Hasil yang diperoleh menunjukkan bahwa jumlah larva ikan yang tertangkap sebanyak 1.089 individu terdiri dari 7 famili yakni: Ambassidae $\left(260 \mathrm{ind} / 100 \mathrm{~m}^{3}\right)$, Nemipteridae $\left(94 \mathrm{ind} / 100 \mathrm{~m}^{3}\right)$, Engraulidae $\left(424 \mathrm{ind} / 100 \mathrm{~m}^{3}\right)$, Apogonidae $\left(20 \mathrm{ind} / 100 \mathrm{~m}^{3}\right)$, Mugilidae $\left(156 \mathrm{ind} / 100 \mathrm{~m}^{3}\right)$, Gobidae $\left(37 \mathrm{ind} / 100 \mathrm{~m}^{3}\right)$, dan Chanidae $\left(98 \mathrm{ind} / 100 \mathrm{~m}^{3}\right)$. Larva ikan famili Engraulidae tertangkap paling banyak selama dilakukan penelitian. Berdasarkan analisis indeks Morisita, pola distribusi larva ikan adalah acak. Kesimpulan yang dapat diperoleh ialah nilai kelimpahan larva ikan tertinggi terdapat pada ekosistem pantai sebesar $673 \mathrm{ind} / 100 \mathrm{~m}^{3}$ dan terendah terdapat pada ekosistem muara sebesar $188 \mathrm{ind} / 100 \mathrm{~m}^{3}$. Nilai keanekaragaman pada ekosistem pantai, muara, dan mangrove tergolong sedang. Nilai keseragaman di semua ekosistem pengambilan sampel termasuk tinggi. Nilai indeks dominasi pada setiap ekosistem termasuk dalam kriteria nilai yang mendekati 0 , yang dapat diartikan tidak ada individu yang mendominasi. Hasil uji Kruskal Wallis untuk nilai kelimpahan larva ikan menunjukkan terdapat perbedaan kelimpahan larva ikan yang nyata di setiap ekosistem. Keterkaitan parameter lingkungan dengan kelimpahan larva ikan yang di uji menggunakan regresi linier berganda menunjukkan nilai korelasi (R) yang termasuk ke dalam kriteria hubungan sedang, untuk nilai determinasi $\left(\mathrm{R}^{2}\right)$ sebesar 0,131 yang menunjukkan $13,1 \%$ kelimpahan ikan dipengaruhi oleh parameter lingkungan.
\end{abstract}

Kata kunci: Larva ikan, Distribusi dan Kelimpahan, Perairan Desa Mangunharjo

\section{ABSTRACT}

The distribution and abundance of fish larvae depends on the condition of the waters. The waters of Mangunharjo Village are unique because they have three different ecosystems, the first coastal ecosystem, the two estuarine ecosystems, and the last of the mangrove ecosystem. This study aims to determine the distribution patterns and abundance of fish larvae in three different ecosystems in the waters of Mangunharjo Village. The research was conducted on July-August 2017. The research method used the survey, with sistematic random sampling point. The results showed amount of fish larvae caught were 1,089 individuals consisting of 7 families, that is Ambassidae (260

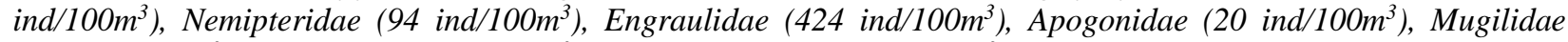
$\left(156\right.$ ind $\left./ 100 \mathrm{~m}^{3}\right)$, Gobidae $\left(37\right.$ ind $\left./ 100 \mathrm{~m}^{3}\right)$, and Chanidae $\left(98\right.$ ind $\left./ 100 \mathrm{~m}^{3}\right)$. The most larvae caught on the study is Engraulidae family. Based on the Morisita index analysis, the pattern of fish larvae distribution is random. The conclusion that can be obtained is the highest value of fish larvae abundance found in the coastal ecosystem of 673 ind / 100m3 and the lowest is in the estuary ecosystem of 188 ind / 100m3. The value of diversity in coastal, estuarine and mangrove ecosystems is moderate. The value of uniformity in all sampling ecosystems is high. The value of the dominance index in all ecosystem is included in the criterion of value close to 0 , which can be interpreted as no individual dominates. The Kruskal Wallis test results for the fish larvae abundance values indicate that there are

\footnotetext{
${ }^{\odot}$ Copyright by Management of Aquatic Resources (MAQUARES)
} 
differences in fish larva abundance which is evident in each ecosystem. The correlation of environmental parameters with abundance of fish larvae tested using multiple linear regression showed correlation value $(R)$ belonging to

intermediate correlation criterion, for determination value (R2) equal to 0,131 showing 13,1\% fish abundance influenced by environmental parameter.

Keywords: Fish larvae, Distribution and Abundance, Waters of Mangunharjo Village

\section{PENDAHULUAN}

Daerah pantai, muara dan mangrove merupakan suatu komponen ekosistem pesisir yang dikenal sangat produktif dan paling mudah terganggu oleh adanya tekanan lingkungan yang terjadi karena kegiatan manusia, seperti pembangunan yang berlebihan di daerah pesisir maupun proses-proses alamiah seperti arus dan gelombang yang mengakibatkan abrasi. Selain itu sebagian besar penduduk dunia (hampir mencapai 70\%) termasuk Indonesia bermukim di sekitar wilayah pesisir dan sepanjang tepian sungai yang mengakibatkan terjadinya tekanan lingkungan di daerah pesisir (Dahuri, 1992).

Perairan Desa Mangunharjo termasuk ekosistem yang unik sebagai hasil interaksi antara ekosistem pantai, ekosistem hutan muara sungai, dan ekosistem mangrove. Wilayah tersebut dipengaruhi oleh pasang surut air laut dan mendapat pasokan air tawar yang berasal dari sungai irigasi utara, selain itu Desa Mangunharjo juga memiliki vegetasi mangrove yang masih cukup baik dibandingkan dengan daerah lainya di Kota Semarang. Menurut penelitian yang dilakukan oleh Fatah (2014) penanaman mangrove besar-besaran berawal pada tahun 2010, dimulai dari petani tambak Desa Mangunharjo, instansi atau sponsor, serta relawan asing yang membantu terlaksananya penanaman mangrove. Budidaya tanaman mangrove juga dilakukan masyarakat secara kelompok yang dibantu oleh sponsor. Perkembangan penanaman mangrove dapat dilihat pada Tabel 1.

Menurut Beck et al., (2001) dalam Suryandari (2012) sebagian besar kelangsungan hidup ikan laut pada fase larva tidak dapat dipisahkan dengan ekosistem estuaria. Estuaria merupakan wilyah pesisir semi tertutup yang memiliki hubungan bebas dengan laut terbuka dan menerima masukan air tawar dari daratan. Ekosistem estuaria dengan produktivitas yang tinggi merupakan salah satu habitat yang memiliki daya dukung untuk berkembangbiaknya berbagai jenis biota akuatik termasuk ikan. Ekosistem estuaria seringkali berasosiasi dengan hutan mangrove yang secara ekologi berperan sebagai habitat asuhan (nursery ground), habitat pemijahan (spawning ground) dan habitat mencari makan (feeding ground) bagi biota akuatik seperti ikan, udang dan gastropoda.

Ekosistem pantai, muara, dan mangrove secara alami selama kurun waktu tertentu dapat mengalami perubahan kondisi kualitas perairan seperti meningkatnya kekeruhan dan sedimentasi yang disebabkan masukan air tawar dari daratan yang membawa sedimen serta bahan organik dan anorganik tersuspensi. Hal ini terjadi pula di perairan Mangunharjo Kecamatan Tugu Semarang. Meningkatnya kekeruhan (turbiditas) perairan dapat menghalangi penetrasi sinar matahari di perairan sehingga mengganggu proses fotosintesis fitoplankton yang merupakan sumber makanan bagi organisme akuatik termasuk larva ikan. Peningkatan turbiditas dan sedimen tersuspensi juga dapat mengurangi oksigen terlarut dalam kolom air sehingga mengganggu proses pernafasan bahkan meningkatkan mortalitas telur dan larva ikan (Suryandari, 2012) Tujuan dari penelitian ini adalah berikut:

1. Mengetahui distribusi dan kelimpahan larva ikan yang terdapat di ekosistem pantai, muara, dan mangrove kawasan perairan Desa Mangunharjo Kecamatan Tugu Kota Semarang.

2. Mengetahui perbedaan kelimpahan dan keanekaragaman larva ikan pada ekosistem yang berbeda di kawasan perairan Desa Mangunharjo Kecamatan Tugu Kota Semarang.

3. Mengetahui keterkaitan parameter lingkungan dengan kelimpahan larva ikan di kawasan perairan Desa Mangunharjo Kecamatan Tugu Kota Semarang.

\section{MATERI DAN METODE}

Materi yang digunakan dalam penelitian Komposisi Larva Ikan di Kawasan Perairan Desa Mangunharjo Kecamatan Mangunharjo, Tugu, Semarang adalah sampel larva ikan yang tertangkap menggunakan alat tangkap jarring larva.

\section{Materi}

Alat yang digunakan untuk sampling lapangan adalah jaring larva ukuran mesh size $0,5 \mathrm{~mm}$, botol sampel, GPS, kertas label, kamera digital dan alat tulis. Alat yang digunakan pada saat pengukuran kualitas air yaitu, termometer air raksa, bola arus, refraktometer, secchi disk, $\mathrm{pH}$ universal untuk. Alat yang digunakan di laboratorium yaitu buku identifikasi larva ikan (Leis dan Brooke, 2000), penggaris, stereo microscope, cawan petri, alat bedah

${ }^{\circ}$ Copyright by Management of Aquatic Resources (MAQUARES) 
(sectio kit), dan form identifikasi larva dan alat tulis. Bahan yang digunakan dalam penelitian ini adalah larva ikan sebagai sampel untuk diidentifikasi, formalin $4 \%$ untuk mengawetkan larva ikan, $\mathrm{MnSO}_{4}, \mathrm{H}_{2} \mathrm{SO}_{4}, \mathrm{NaOH}$ dalam $\mathrm{KI}$, $\mathrm{N}_{2} \mathrm{~S}_{2} \mathrm{O}_{3}$ dan amilum untuk mengukur nilai oksigen terlarut.

\section{Metode}

Metode yang digunakan dalam penelitian ini adalah metode deskriptif, yang memiliki tujuan untuk menggambarkan keadaan suatu objek dalam pengamatan (Furchan, 2004) serta variabel yang diteliti tidak di manipulasi atau tidak ada perlakuan (treatment) (Kountur, 2003). Obyek yang diamati yaitu distribusi dan kelimpahan larva ikan.

\section{Pengambilan Sampel}

Data yang digunakan pada penelitian ini adalah data primer. Data primer merupakan suatu data yang diperoleh secara langsung dari hasil sampling di lapangan. Data tersebut digunakan peneliti sebagai sumber kajian penelitian untuk memperoleh hasil dan kesimpulan dalam penelitian. Pengambilan data penelitian dilakukan sebanyak 3 pengulangan selama tiga minggu yaitu pada tanggal 26 Juli 2017, 1 Agustus 2017, dan 7 Agustus 2017.

\section{Penentuan Lokasi Pengambilan Sampel}

Metode yang digunakan untuk menentukan titik sampling adalah metode systematic random yaitu menganggap bahwa sample yang diambil dapat mewakili populasi. Titik sampling yang diambil berjumlah sembilan titik karena untuk mewakili ketiga ekosistem yang di teliti: Ekosistem Pantai (titik 1,2,3), Ekosistem Muara (titik 4,5,6) dan Ekosistem Mangrove (titik 7,8,9) (Gambar 3)

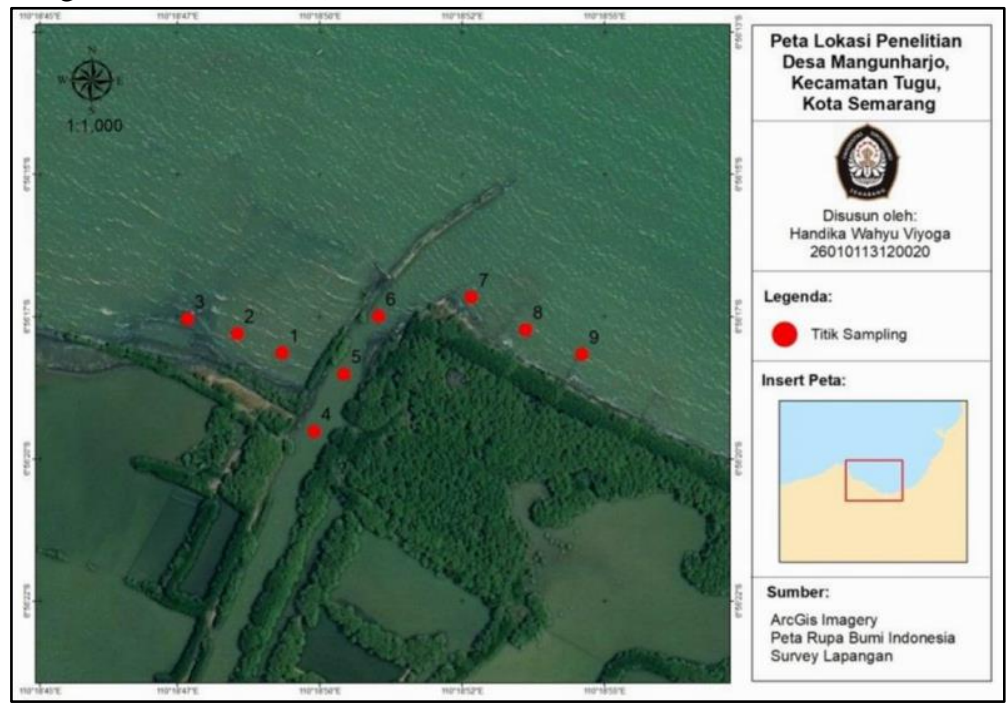

Gambar 1. Titik Pengambilan Sampel

Pengambilan Sampel Larva Ikan

Pengambilan sampel larva ikan dilakukan di kawasan perairan di Mangunharjo sebanyak tiga kali pengambilan sampel yang dilakukan secara pasif, yaitu dilakukan secara manual dengan menarik jaring larva yang dilakukan oleh peneliti dengan jarak 25 meter di setiap titiknya (Gambar 4) (Riswandha, 2015). Jaring larva yang digunakan berukuran $2 \times 1$ meter dengan mesh size $1 \mathrm{~mm}$, dimana dalam proses pengambilan sampel larva ikan dilakukan penyisiran sebanyak 2 kali pengulangan dengan mengikuti bentuk pola yang telah ditentukan. Berikut ini merupakan gambar ilustrasi teknik pengambilan sampel larva ikan dan arah arus perairan di lokasi studi: 


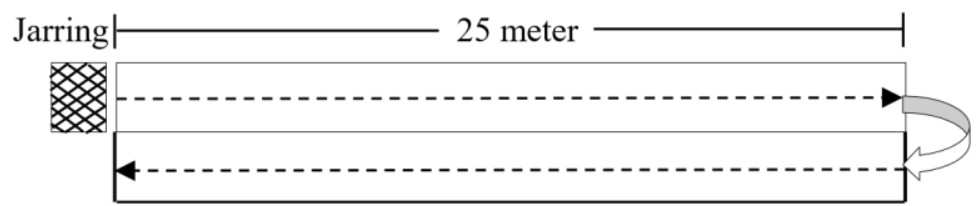

Gambar 2. Ilustrasi Teknik Pengambilan Sampel Larva Ikan

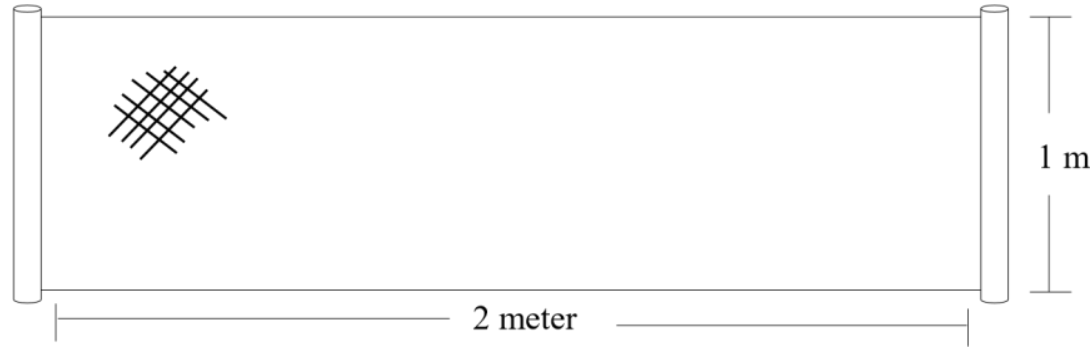

Gambar 3. Jaring Larva Sebagai Alat Tangkap Larva Ikan

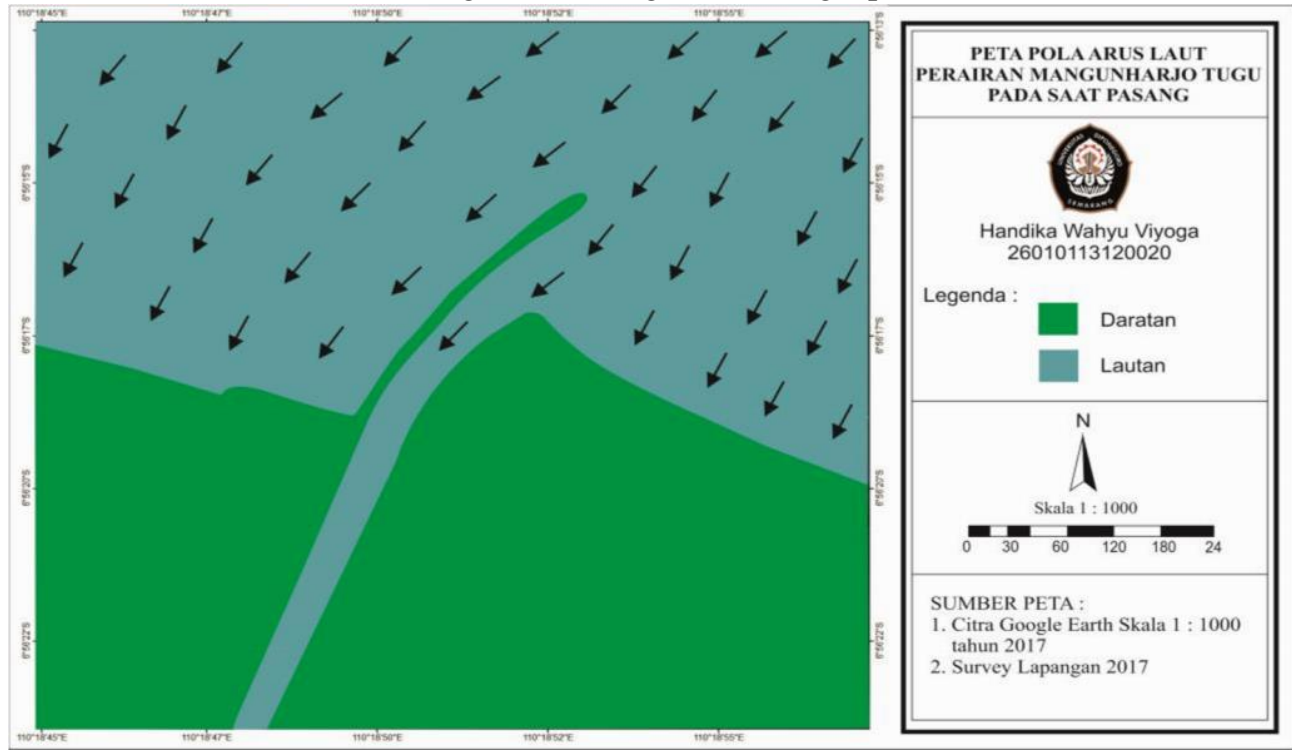

Gambar 4. Arah Arus Perairan pada saat Pasang 


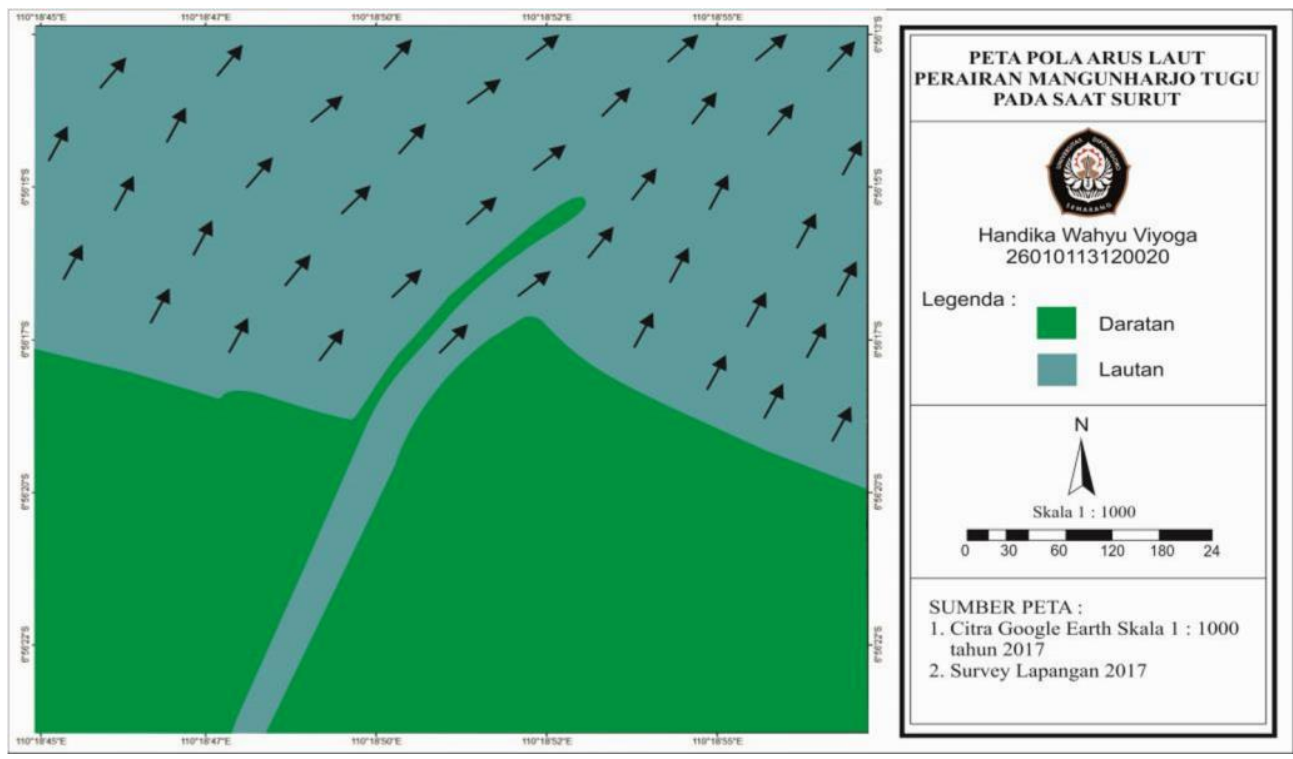

Analisa Data

Gambar 5. Arah Arus Perairan pada saat Surut

Distribusi Larva Ikan Pola penyebaran larva ikan dalam penelitian ini ditentukan dengan menggunakan Indeks Morisita (I $\delta$ ). Indeks ini tidak dipengaruhi oleh luas stasiun pengambilan sampel dan sangat baik untuk membandingkan pola distribusi populasi (Brower, et al., 1990 dalam Anwar, 2008). Rumus yang digunakan adalah sebagai berikut:

Keterangan:

$$
\mathrm{I} \delta=\mathrm{n} \frac{\sum X i 2-N}{N(N-1)}
$$

I $\delta \quad=$ Indeks distribusi Morisita

$\mathrm{N}=$ Jumlah seluruh individu dalam total $\mathrm{n} \mathrm{n}$

$=$ Jumlah seluruh stasiun pengambilan contoh

$\sum \mathrm{Xi}^{2}=$ Kuadrat jumlah larva jenis $\mathrm{i}$ per stasiun untuk total $\mathrm{n}$ stasiun

Hasil indeks Morisita yang diperoleh di kelompokkan sebagai baerikut:

I $\delta<1 \quad$ : Pola sebaran individu bersifat acak

$\mathrm{I} \delta=1 \quad$ : Pola sebaran individu bersifat merata

I $\delta>1$ : Pola sebaran individu bersifat berkelompok

\section{Kelimpahan Larva Ikan}

Kelimpahan larva ikan didefinisikan sebagai banyaknya larva ikan per satuan luas daerah pengambilan, menurut Suryandari (2012) kelimpahan larva dihitung dengan menggunakan rumus sebagai berikut:

$$
\mathrm{N}=\mathrm{n} / \mathrm{Vtsr}
$$

Keterangan:

(ind $/ \mathrm{m}^{3}$ )

$$
\mathrm{N}=\text { Kelimpahan larva ikan }
$$

yang tercacah (ind)

\section{Struktur komunitas Larva Ikan}

$$
\mathrm{n}=\text { Jumlah larva ikan }
$$

$$
\text { Vtsr }=\text { Volume air tersaring }(\mathrm{Vtsr}=\text { luas jaring } \mathrm{x} \text { panjang penarikan })
$$

Indeks keanekaragaman (H') dapat diartikan sebagai suatu penggambaran secara sistematik yang melukiskan struktur komunitas dan dapat memudahkan proses analisa informasi-informasi mengenai macam dan jumlah organisme. Semakin banyak jenis yang ditemukan maka keanekaragaman akan semakin besar meskipun nilai ini sangat tergantung dari jumlah individu masing-masing jenis. Selanjutnya menurut Krebs (1999), semakin banyak

\footnotetext{
${ }^{\circledR}$ Copyright by Management of Aquatic Resources (MAQUARES)
} 
jumlah anggota individunya dan merata maka indeks keanekaragaman juga akan semakin besar. Menurut Odum (1993), untuk perhitungan keanekaragaman digunakan indeks Shannon-Wiener:

$$
\begin{aligned}
\mathrm{H}^{\prime}=-\sum_{n=1}^{s_{n=1}} p i \ln p i \text { Keterangan: } \\
\mathrm{H}^{\prime}=\text { Indeks Keanekaragaman Shannon-Wiener }
\end{aligned}
$$

$\mathrm{pi}=$ perbandingan jumlah individu ke-i dengan jumlah total individu

$(\mathrm{ni} / \mathrm{N}) \quad \mathrm{ni}=$ jumlah individu suatu jenis

$\mathrm{N}=$ jumlah individu seluruh jenis

Menurut Wilhm and Dorris (1986), kriteria indeks keanekaragaman dibagi dalam 3

kategori yaitu: $\mathrm{H}^{\prime}<1 \quad$ : Keanekaragaman jenis rendah $1<\mathrm{H}^{\prime}<3$ : Keanekaragaman

jenis sedang

$\mathrm{H}^{\prime}>3 \quad$ : Keanekaragaman jenis tinggi

Indeks keseragaman (e) adalah komposisi tiap individu pada suatu spesies yang terdapat dalam suatu komunitas. Indeks keseragaman (e) merupakan pendugaan yang baik untuk menentukan dominasi dalam suatu area, apabila satu atau beberapa jenis melimpah dari yang lainnya maka indeks keseragaman akan rendah. Keseragaman jenis dapat dibandingkan dengan indeks keseragaman yaitu dengan nilai maksimumnya, menggunakan rumus sebagai berikut:

Keterangan:

$$
\mathrm{e}=\frac{H^{\prime}}{H \max }
$$

$\mathrm{e}=$ Indeks keseragaman

$\mathrm{H}^{\prime}=$ Indeks keanekaragaman Shannon-Wiener

$\mathrm{H} \max =\log _{2} \mathrm{~S}=$ Indeks keanekaragaman maksimum

$\mathrm{s}=$ Jumlah maksimum

Dimana menurut Odum (1971) indeks keseragaman berkisar 0-1 dengan klasifikasi sebagai berikut:

$0,6-1$ : Tingkat keseragaman populasi tinggi

$0,4-0,6 \quad$ : Tingkat keseragaman populasi sedang

$0-0,4 \quad$ : Tingkat keseragaman populasi rendah

Indeks dominansi $(\mathrm{C})$ digunakan untuk mengetahui sejauh mana suatu kelompok biota mendominansi kelompok lain. Dominansi yang cukup besar akan mengarah pada komunitas yang labil maupun tertekan. Perhitungan indeks dominansi menggunakan rumus sebagai berikut (Odum ,1971):

Keterangan:

$$
\mathrm{C}=\sum\left(\frac{n i}{N}\right)^{2}
$$

$\mathrm{C}=$ Indeks Dominansi Simpson $(0-1,0)$

$\mathrm{ni}=$ Jumlah individu ke i $\mathrm{n}=$ Jumlah total

individu

Nilai $\mathrm{C}$ berkisar antara 0,0-1,0 apabila nilai $\mathrm{C}$ mendekati 0,0 berarti hampir tidak ada individu yang mendominasi dan biasanya diikuti nilai e yang besar (mendekati 1), sedangkan apabila nilai $\mathrm{C}$ mendekati 1 berarti terjadi dominasi jenis tertentu dan dicirikan dengan nilai e yang lebih kecil atau mendekati 0 .

\section{Perbedaan Nilai Kelimpahan Larva Ikan}

Uji Kruskal-Wallis digunakan untuk mengetahui perbedaan nilai kelimpahan larva ikan di setiap stasiunya, distribusi dari nilai pada variabel kuantitatif yang diperoleh merupakan dari dua atau lebih kelompok. Analisis data tersebut diterapkan di situasi data yang sama sebagai ANOVA untuk sampel yang independen, kecuali digunakan untuk data yang distribusinya tidak normal. Skala pengukuran variabel dependen adalah ordinal (tidak interval atau rasio), atau dari sampel terlalu kecil. Hasil akhir dari uji kruskal wallis adalah nilai P value, yaitu apabila nilainya > batas kritis 0,05 atau mendekati 0,05 (Yanti, 2010)

\section{Keterkaitan Parameter Lingkungan dengan Kelmpahan Larva}

Data diolah menggunakan uji regresi linear berganda untuk mengetahui besarnya hubungan dan pengaruh variabel bebas (independen) $\mathrm{X}_{1}$ (suhu), $\mathrm{X}_{2}(\mathrm{DO}), \mathrm{X}_{3}(\mathrm{pH}), \mathrm{X}_{4}$ (salinitas), $\mathrm{X}_{5}$ (arus), $\mathrm{X}_{6}$ (kedalaman), dan $\mathrm{X}_{7}$ (kecerahan) terhadap variabel tak bebas (dependen) Y (kelimpahan larva ikan). Perangkat lunak yang digunakan

\footnotetext{
${ }^{\circledR}$ Copyright by Management of Aquatic Resources (MAQUARES)
} 
untuk analisa data ini adalah SPSS versi 20. Besarnya nilai yang menunjukkan hubungan angka parameter lingkungan dengan kelimpahan larva ikan dapat diketahui menggunakan koefisien korelasi (R), kemudian untuk mengetahui pengaruh parameter lingkungan tersebut terhadap kelimpahan larva dapat menggunakan koefisien determinasi $\left(R^{2}\right)$. Analisis menggunakan taraf kepercayaan sebesar $95 \%(\alpha=0,05)$. Persamaan model regresi linier berganda yaitu $\mathrm{Y}=\mathrm{a}+\mathrm{bX} \mathrm{X}_{1}+\mathrm{bX}_{2}+\ldots \mathrm{bX}$. Analisis regresi bertujuan mempelajari "pengaruh" variabel bebas terhadap variabel tak bebas. Jika skala pengukuran dari beberapa variabel bebas dan sebuah variabel tak bebas yang akan dianalisis merupakan interval atau rasio maka untuk menjelaskan pengaruh atau hubungan antara variabel tersebut dapat dilakukan dengan menggunakan regresi linear ganda dengan dua prediktor. Misalkan variabel bebas tersebut adalah $\mathrm{X}_{1}, \mathrm{X}_{2}$ dan variabel terikatnya adalah $\mathrm{Y}$, maka pengaruh $\mathrm{X}_{1}, \mathrm{X}_{2}$ terhadap $\mathrm{Y}$ atau dinamakan regresi ganda $\mathrm{Y}$ atas $\mathrm{X}_{1}, \mathrm{X}_{2}$ (Kadir, 2015).

Menurut Razak (1991) dalam Mutaqin et al., 2014) nilai keeratan dikategorikan :

$0,00-0,20 \quad=$ hubungan sangat lemah

$0,21-0,40 \quad=$ hubungan lemah

$0,41-0,70 \quad=$ hubungan sedang

0,71-0,90= hubungan kuat

0,91-1,00 = hubungan sangat kuat

Koefisien korelasi (R) dipakai hanya untuk menyatakan keeratan hubungan yang bersifat linier sederhana. Koefisien determinasi $\left(\mathrm{R}^{2}\right)$ mencerminkan seberapa besar variabel dependen dapat diterangkan oleh variabel independen (Mutaqin et al., 2014).

\section{HASIL DAN PEMBAHASAN}

Hasil

Parameter Kimia Fisika Perairan

Pengukuran parameter fisika dan kimia di kawasan perairan Desa Mangunharjo dilakukan secara in situ pada lokasi penelitian yang digunakan sebagai data variabel lingkungan pendukung.

\begin{tabular}{|c|c|c|c|c|c|c|c|c|c|c|}
\hline \multirow[t]{2}{*}{ No } & \multirow[t]{2}{*}{ Variabel } & \multicolumn{3}{|c|}{ Pantai } & \multicolumn{3}{|c|}{ Muara } & \multicolumn{3}{|c|}{ Mangrove } \\
\hline & & I & II & III & I & II & III & I & II & III \\
\hline \multicolumn{11}{|c|}{ Tabel 1. Hasil Rerata Pengukuran Parameter Fisika dan Kimia Selama 3 Minggu } \\
\hline 1 & $\operatorname{Kecerahan}(\mathrm{m})$ & 0,4 & 0,35 & 0,34 & 0,36 & 0,32 & 0,36 & 0,38 & 0,29 & 0,43 \\
\hline 2 & Kedalaman (m) & 0,85 & 0,9 & 0,68 & 1,52 & 1,48 & 1,39 & 0,88 & 0,89 & 0,95 \\
\hline 3 & $\begin{array}{l}\text { Kecepatan arus } \\
(\mathrm{m} / \mathrm{s})\end{array}$ & 0,05 & 0,04 & 0,04 & 0,06 & 0,07 & 0,06 & 0,05 & 0,05 & 0,06 \\
\hline 4 & Temperatur $\left({ }^{\circ} \mathrm{C}\right)$ & 29,5 & 29,5 & 29,5 & 29 & 29 & 29 & 29 & 29 & 30 \\
\hline 5 & $\mathrm{pH}$ & 6 & 6 & 6 & 6 & 6 & 6 & 6 & 6 & 6 \\
\hline 6 & Salinitas $(\%$ оo & 28,6 & 28,6 & 27,3 & 26,3 & 26 & 25,6 & 29,6 & 29,3 & 29,6 \\
\hline$\underline{7}$ & $\underline{\mathrm{DO}}(\mathrm{mg} / \mathrm{l})$ & $\underline{4,87}$ & $\underline{5,25}$ & $\underline{5,61}$ & $\underline{5,06}$ & $\underline{5,01}$ & $\underline{5,22}$ & $\underline{5,5}$ & $\underline{5,61}$ & $\underline{5,76}$ \\
\hline
\end{tabular}

Berdasarkan hasil yang tertera pada Tabel 3. dapat dilihat bahwa pengukuran variabel kecerahan, kedalaman, kecepatan arus dan temperatur memiliki perubahan yang tidak begitu signifikan. Hasil pengukuran variabel kecerahan berkisar antara 0,29-0,43 m, kedalaman berkisar antara 0,65 - 1,52 m, kecepatan arus berkisar antara $0,04-0,07 \mathrm{~m} / \mathrm{s}$ dan temperatur berkisar antara $29-30{ }^{\circ} \mathrm{C}$. Pengukuran variabel $\mathrm{pH}$ air di Perairan Desa Mangunharjo setiap minggunya bernilai 6 , hasil $\mathrm{pH}$ air yang didapatkan relatif sama di semua ekosistem. Nilai salinitas air yang didapatkan berkisar antara $25-29 \%$. Nilai kandungan oksigen terlarut pada lokasi penelitian berkisar antara 4,8 - 5,7 mg/l, untuk nilai terendah 4,87 mg/l terdapat pada daerah pantai dan nilai tertinggi terdapat pada daerah mangrove yaitu $5,76 \mathrm{mg} / \mathrm{l}$.

\section{Komposisi Larva Ikan}

Larva ikan yang berhasil teridentifikasi di Kawasan Perairan Estuari Mangunharjo Kecamatan Tugu Kota

${ }^{\odot}$ Copyright by Management of Aquatic Resources (MAQUARES) 
Semarang sebanyak 1.089 individu yang terdiri dari 7 famili yaitu Ambassidae, Mugilidae, Chanidae, Engraulidae, Apogonidae, Nemipteridae, dan Gobiidae. Komposisi larva ikan yang tertangkap secara keseluruhan berdasarkan titik pengambilan sampel tersaji dalam Gambar 9 dan Tabel 4

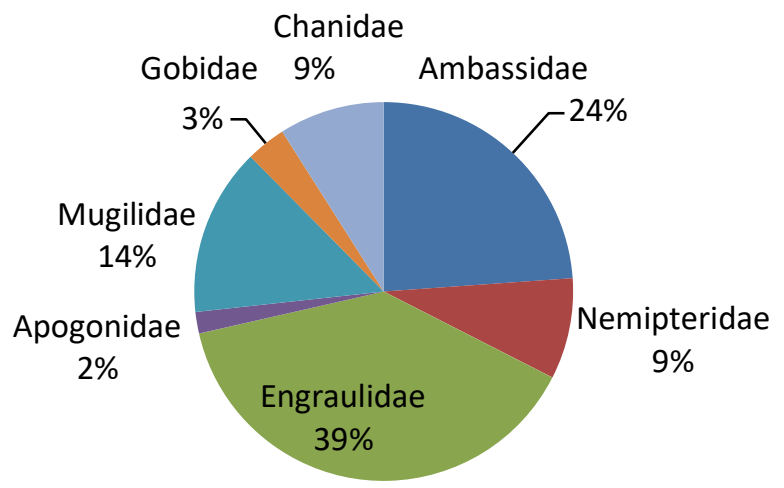

Gambar 6. Persentase Jenis dan Jumlah Larva yang Tertangkap

Tabel 2. Komposisi Jenis dan Jumlah Larva Ikan yang Tertangkap di Tiap Titik Lokasi Pengambilan Sampel (Individu $/ 100 \mathrm{~m}^{3}$ )

\begin{tabular}{|c|c|c|c|c|c|c|c|c|c|c|}
\hline \multirow{3}{*}{ No } & \multirow{3}{*}{ Famili } & \multicolumn{9}{|c|}{ Titik Sampling } \\
\hline & & \multicolumn{3}{|c|}{ Pantai } & \multicolumn{3}{|c|}{ Muara } & \multicolumn{3}{|c|}{ Mangrove } \\
\hline & & 1 & 2 & 3 & 1 & 2 & 3 & 1 & 2 & 3 \\
\hline 1 & Ambassidae & 32 & 86 & 41 & 0 & 0 & 8 & 46 & 21 & 26 \\
\hline 2 & Nemipteridae & 33 & 18 & 33 & 0 & 0 & 0 & 10 & 0 & 0 \\
\hline 3 & Engraulidae & 70 & 99 & 155 & 0 & 12 & 42 & 24 & 22 & 0 \\
\hline 4 & Apogonidae & 0 & 4 & 0 & 0 & 7 & 9 & 0 & 0 & 0 \\
\hline 5 & Mugilidae & 39 & 37 & 0 & 0 & 0 & 37 & 43 & 0 & 0 \\
\hline 6 & Gobidae & 0 & 0 & 0 & 4 & 0 & 0 & 7 & 9 & 17 \\
\hline \multirow[t]{2}{*}{7} & Chanidae & 0 & 4 & 22 & 38 & 3 & 28 & 0 & 0 & 3 \\
\hline & Jumlah & 174 & 248 & 251 & 42 & 22 & 124 & 130 & 52 & 46 \\
\hline
\end{tabular}

Sumber : Penelitian 2017

Berdasarkan Gambar 9 dan Tabel 4 dapat dilihat bahwa terdapat jenis larva yang paling sedikit yaitu jenis Apogonidae yang tertangkap dengan jumlah individu 20 dengan persentase kemunculan $2 \%$, sedangkan jenis larva yang paling banyak tertangkap adalah jenis Engraulidae dengan jumlah individu 424 dengan persentase kemunculan $39 \%$. Setiap titik pengambilan sampel larva yang tertangkap berbeda-beda jenis. Tidak semua jenis larva terdapat pada titik yang sama. Pada ekosistem pantai larva yang paling banyak tertangkap yaitu famili Engraulidae 324 ind $/ 100 \mathrm{~m}^{3}$,. Pada ekosistem muara larva yang paling banyak tertangkap yaitu famili Chanidae $69 \mathrm{ind} / 100 \mathrm{~m}^{3}$. Pada ekosistem mangrove larva famili Ambassidae tertangkap paling banyak yaitu $93 \mathrm{ind} / 100 \mathrm{~m}^{3}$. Jenis larva yang paling sedikit tertangkap yaitu famili Apogonidae yang hanya di temukan di ekosistem pantai dan muara dengan jumlah 20 ind $/ 100 \mathrm{~m}^{3}$. Distribusi Larva Ikan

Berdasarkan analisis pola distribusi jenis individu dengan menggunakan Indeks Morista, diperoleh hasil bahwa pola distribusi setiap jenis larva yang tertangkap mempunyai kisaran nilai yang kurang dari 1 yang berarti pola distribusinya acak

Tabel 3. Nilai Indeks Morisita Jenis Larva Ikan yang Tertangkap di Kawasan Perairan Desa Manhunharjo

\begin{tabular}{clcc} 
No & Famili & Nilai Indeks Morisita & Keterangan \\
\hline 1 & Ambassidae & 0,194 & Acak \\
2 & Nemipteridae & 0,284 & Acak \\
3 & Engraulidae & 0,230 & Acak
\end{tabular}

${ }^{\odot}$ Copyright by Management of Aquatic Resources (MAQUARES) 


$\begin{array}{llll}4 & \text { Apogonidae } & 0,317 & \text { Acak } \\ 5 & \text { Mugillidae } & 0,245 & \text { Acak } \\ 6 & \text { Gobidae } & 0,292 & \text { Acak } \\ 7 & \text { Chanidae } & 0,276 & \text { Acak }\end{array}$

Sumber : Penelitian 2017

\section{Kelimpahan Larva Ikan}

Hasil perhitungan kelimpahan rata-rata (ind/100 $\mathrm{m}^{3}$ ) larva ikan di Kawasan Perairan Desa Mangunharjo tersaji dalam Gambar 7.
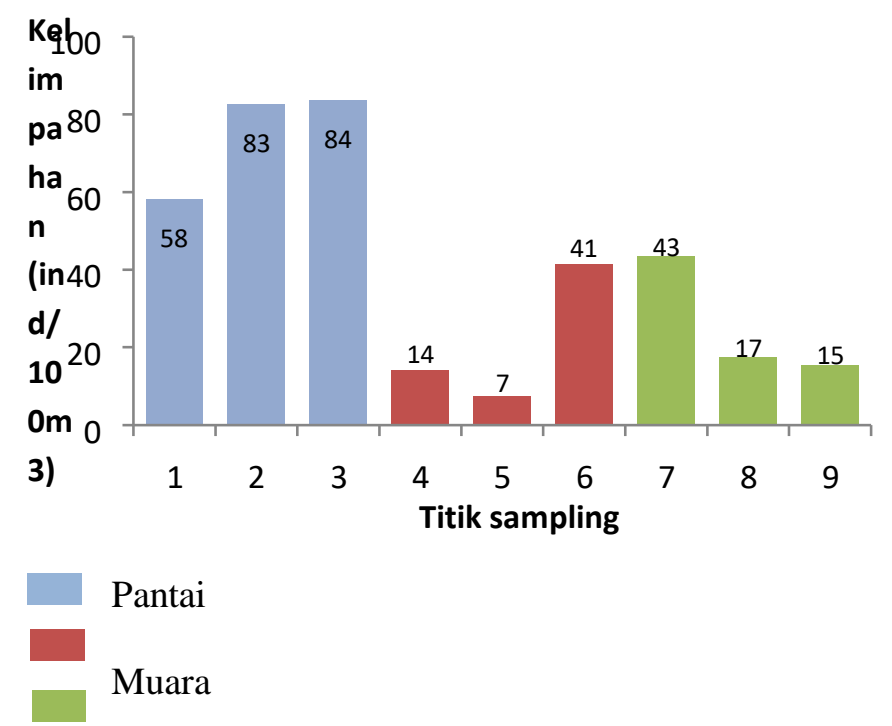

Gambar 7. Kelimpahan Larva Ikan di Kawasan Perairan Desa Mangunharjo

Kelimpahan rata-rata larva ikan tertinggi ditemukan pada ekosistem pantai sebesar 75 ind $/ 100 \mathrm{~m}^{3}$, diikuti kelimpahan rata-rata larva ikan di ekosistem mangrove sebesar $25 \mathrm{ind} / 100 \mathrm{~m}^{3}$, sedangkan kelimpahan rata-rata larva ikan terendah ditemukan pada ekosistem muara sebesar $21 \mathrm{ind} / 100 \mathrm{~m}^{3}$.

Struktur Komunitas Larva Ikan dalam Tabel 4.

Nilai indeks keanekaragaman, keseragaman, dan dominasi di Kawasan Perairan Estuari Mangunharjo tersaji

Tabel 4. Struktur Komunitas Larva Ikan di Kawasan Perairan Desa Mangunharjo

\begin{tabular}{llccc}
\hline No & Struktur Komunitas & Pantai & Muara & Mangrove \\
\hline 1 & Jumlah Spesies & 6 & 6 & 6 \\
2 & Jumlah Individu (ind/100m $\left.{ }^{3}\right)$ & 673 & 188 & 228 \\
3 & Keanekaragaman (H') & 1,355 & 1,472 & 1,477 \\
4 & Keseragaman (E) & 0,756 & 0,822 & 0,824 \\
5 & Dominasi (C) & 0,317 & 0,265 & 0,266 \\
\hline
\end{tabular}

Sumber : Penelitian 2017

Jenis spesies yang ditemukan setiap ekosistem pengambilan sampel berjumlah 6 jenis larva ikan. Nilai indeks keanekaragaman pada ekosistem pantai, muara, dan mangrove termasuk dalam kriteria nilai $1>\mathrm{H}^{\prime}<3$ sehingga tingkat keanekaragamanya tergolong sedang. Nilai indeks keseragaman pada semua ekosistem pengambilan sampel termasuk dalam kriteria nilai 0,6 - 1 sehingga tingkat keseragaman populasi tinggi. Nilai indeks dominasi pada

${ }^{\odot}$ Copyright by Management of Aquatic Resources (MAQUARES) 
setiap ekosistem pengambilan sampel termasuk dalam kriteria nilai mendekati 0 , sehingga hampir tidak ada individu yang mendominasi.

\section{Perbedaan Nilai Kelimpahan di Setiap Ekosistem}

Uji Kruskal-Wallis pada penelitian ini digunakan untuk melihat perbedaan distribusi dari nilai variabel kuantitatif yang diperoleh dari dua atau lebih kelompok. Nilai kelimpahan larva ikan merupakan variabel yang diuji dengan Uji Kruskal-Wallis. Hasil Uji Kruskal-Wallis dengan membandingkan nilai kelimpahan larva berdasarkan

\begin{tabular}{cc}
\hline Analisa Uji & Asymp. Sig. \\
Ekosisitem pantai : muara : mangrove & \\
\hline
\end{tabular}

stasiunnya dapat dilihat pada Tabel 5 yang merupakan kesimpulan dari lampiran 7

Tabel 5.Hasil Signifikasi Uji Kruskal-Wallis Kelimpahan dan Keanekaragaman Larva dibandingkan berdasarkan Kelimpahan $0,041^{*}$ Ekosistem Pantai, Muara, dan Mangrove.

Keanekaragaman 0,733

*) Correlation is significant at the 0,05 level

Berdasarkan Tabel 7 dapat diketahui bahwa yang memiliki hubungan antara ekosistem pantai, muara dan mangrove di masing-masing variabel uji adalah variabel kelimpahan dan keanekaragaman larva ikan. Pada kelimpahan larva ikan didapatkan $\alpha<0,05$ yang artinya bahwa nilai kelimpahan larva ikan pada ekosistem pantai dapat dianggap memiliki perbedaan nyata dengan ekosistem muara dan ekosistem mangrove. Sedangkan untuk nilai keanekaragaman larva ikan didapatkan $\alpha>0,05$ yang artinya bahwa nilai keanekaragaman larva ikan pada ekosistem pantai, ekosistem muara dan ekosistem mangrove tidak memiliki perbedaan nilai yang nyata.

\section{Keterkaitan Parameter Lingkungan dengan Kelimpahan Larva Ikan}

Persamaan linier untuk menganalisa keterkaitan parameter lingkungan dengan kelimpahan larva ikan adalah sebagai berikut $\mathrm{Y}=\mathrm{a}+\mathrm{bX} \mathrm{X}_{1}+\mathrm{bX} \mathrm{X}_{2}+\mathrm{bX} \mathrm{X}_{3}+\mathrm{b} \mathrm{X}_{4}+\mathrm{bX} \mathrm{X}_{5}+\mathrm{bX} \mathrm{X}_{6}+\mathrm{bX}_{7}$. Hasil analisa yang didapat melalui analisis regresi berganda tersaji pada Tabel 6 dan Lampiran 8 yang menghasilkan rumus:

$$
\begin{gathered}
\mathrm{Y}=38,446+5,512 \mathrm{X}_{1}-12,51 \mathrm{X}_{2}+9,047 \mathrm{X}_{3}-2,373 \mathrm{X}_{4}-620,8 \mathrm{X}_{5}-45,895 \mathrm{X}_{6}+2,535 \mathrm{X}_{7} \\
\begin{array}{c}
\text { Keterangan : } \quad \mathrm{X} 1=\text { suhu } \\
\mathrm{X} 2=\mathrm{DO} \quad \mathrm{X} 5=\text { arus } \\
\mathrm{X} 3=\mathrm{pH}
\end{array} \\
\mathrm{X} 4=\text { salinitas }
\end{gathered}
$$

Tabel 6. Kesimpulan Model Analisis Regresi Linier Berganda

\begin{tabular}{ccccc}
\hline Model & $\mathbf{R}$ & $\mathbf{R}_{2}$ & Adjusted R2 & $\begin{array}{c}\text { Std. Error of } \\
\text { the Estimate }\end{array}$ \\
\hline 1 & 0,604 & 0,365 & 0,131 & 33,99846 \\
\hline
\end{tabular}

Berdasarkan Tabel 8 diperoleh nilai koefisien korelasi (R) sebesar 0,604 yang berarti hubungan parameter lingkungan dengan kelimpahan larva ikan dikategorikan berhubungan sedang. Nilai koefisien determinasi (Adjusted $\mathrm{R}^{2}$ ) sebesar 0,131 nilai ini menunjukkan sebesar 13,1\% kelimpahan larva ikan dipengaruhi oleh parameter lingkungan (suhu, DO, pH, salinitas, arus, kedalaman, kecerahan) sisanya sebesar 86,9\% dipengaruhi oleh faktor lain.

\section{Pembahasan}

\section{Distribusi dan Kelimpahan Larva Ikan}

Komposisi larva ikan yang tertangkap dengan jumlah individu yang cukup besar dijumpai pada ekosisitem pantai dengan jumlah 673 individu. Sedangkan daerah ekosistem muara sungai, larva ikan relatif sedikit dengan 
jumlah 188 individu. Pada ekosistem mangrove didapatkan jumlah larva sebanyak 228 individu.. Pola distribusi pada sampel larva ikan yang diteliti cenderung distribusi pola acak. Pola distribusi acak ini disebabkan karena sifat mobile yang tinggi. Pola penyebaran acak menyebabkan ikan cenderung hidup secara soliter dan ada persaingan antar individu. Hal ini akan menyebabkan tingkat mortalitas larva dan juvenile terhadap adanya predator semakin besar dibandingkan dengan jenis larva yang berkelompok. Banyak faktor yang mempengaruhi distribusi dan persebaran larva ikan salah satunya kondisi perairan, pada ekosistem muara merupakan jalur utama keluar masuk kapal nelayan yang ada di Desa Mangunharjo. Larva cenderung mencari tempat yang aman untuk berlindung, dengan adanya aktifitas manusia yang intens hal ini dapat mengurangi persebaran larva di daerah tersebut, menurut Olii (2003) pada tahap awal daur hidup ikan mempunyai mortalitas yang tinggi karena kepekaan terhadap predator, ketersediaan makanan, dan juga perubahan lingkungan yang terjadi di alam. Dengan terganggunya tahap-tahap awal dari kehidupan ikan maka hal ini memberi dampak nagatif bagi populasi ikan tersebut.

Tangkapan larva ikan di setiap pengulangan mengalami fluktuasi di setiap ekositem. Pengambilan sampel yang pertama, larva ikan paling banyak ditemukan pada ekosistem pantai dengan jumlah larva 282 individu, dan paling sedikit pada ekosistem muara dengan jumlah 68 individu larva. Pengambilan sampel yang kedua, larva paling banyak tertangkap pada ekosistem pantai dengan jumlah larva 140 individu, dan paling sedikit pada ekosistem muara dengan jumlah larva 50 individu. Pengambilan sampel yang ketiga, larva ikan paling banyak ditemukan pada ekosistem pantai dengan jumlah larva 251 individu, dan paling sedikit pada ekosistem mangrove dengan jumlah larva 67 individu. Jumlah tangkapan yang berbeda juga disebabkan adanya faktor internal yaitu efektivitas penangkapan, baik waktu sampling, alat tangkap, jarak sampling dan kemampuan larva ikan itu sendiri untuk menyebar. Hal ini dinyatakan oleh Leis dan Rennis (1983) bahwa banyak larva di perairan yang dangkal mempunyai kemampuan untuk menyebar secara luas dengan jarak sebaran ratusan kilometer.

Jumlah larva ikan yang tertangkap selama penelitian secara keseluruhan berjumlah 1.089 individu. Larva ikan yang berhasil teridentifikasi terdapat 7 famili yakni Ambassidae, Mugilidae, Chanidae, Engraulidae, Lutjanidae, Nemipteridae, dan Gobiidae. Identifikasi larva ikan yang tertangkap dilakukan sampai tahap famili karena kemampuan serta alat yang digunakan tidak mampu melebihi tahap family. Larva paling banyak ditemukan pada saat pengambilan sampel yang pertama dengan jumlah 429 individu, pengambilan sampel yang kedua mendapatkan hasil yang paling sedikit yaitu 274 individu larva, sedangkan pengembilan sampel ketiga mendapatkan jumlah larva 391 individu. Banyaknya larva yang tertangkap saat pengambilan sampel yang pertama bisa di karenakan kondisi perairan yang sedang pasang karena larva masih dipengaruhi oleh adanya pasang surut air laut untuk membantu penyebaranya. Larva Engraulidae merupakan larva ikan yang ditemukan di semua ekosistem penelitian dengan kelimpahan yang tinggi dibandingkan famili lainnya yaitu $424 \mathrm{ind} / 50 \mathrm{~m}^{3}$, diikuti dengan larva jenis Ambassidae

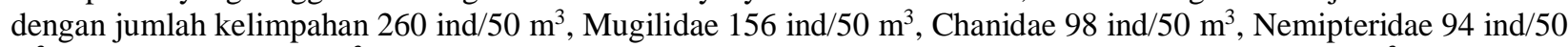
$\mathrm{m}^{3}$, Gobiidae $37 \mathrm{ind} / 50 \mathrm{~m}^{3}$, dan yang paling sedikit dari famili Apagonidae yang berjumlah $20 \mathrm{ind} / 50 \mathrm{~m}^{3}$.

\section{Struktur Komunitas Larva Ikan}

Indeks keanekaragaman (H'), keseragaman (E) dan dominasi (D) digunakan untuk mengetahui pengaruh kualitas lingkungan terhadap komunitas larva ikan. Pengaruh kualitas lingkungan terhadap kelimpahan ikan selalu berbeda-beda tergantung pada jenis ikan, karena setiap ikan memiliki adaptasi dan toleransi yang berbeda terhadap habitatnya. Kondisi lingkungan suatu perairan dikatakan baik bila diperoleh nilai indeks keanekaragaman (H') dan keseragaman (E) yang tinggi, serta indeks dominansi (C) yang rendah (Hukom, 1999).

Indeks keanekaragaman (H') yang diperoleh berdasarkan perhitungan pada setiap ekosistem menunjukkan nilai yang berbeda. Kisaran nilai keanekaragaman $\left(\mathrm{H}^{\prime}\right)$ pada lokasi penelitian yaitu 1,355-1,477 termasuk dalam kriteria nilai $\mathrm{H}^{\prime}$ larva ikan yang tertangkap selama kegiatan penelitian ke dalam tingkat keanekaragaman yang sedang. Menurut Wilham dan Dorris (1968) dalam Suwignyo (1976), indeks keanekaragaman akan mencapai maksimum bila kelimpahan individu perjenis menyebar secara merata. Hal ini berarti dalam suatu komunitas, jumlah individu pada setiap spesiesnya relatif sama atau seragam sehingga tidak ada spesies tertentu yang mendominasi.

Indeks keseragaman (E) digunakan untuk mengetahui berapa besar kesamaan penyebaran jumlah individu setiap genus pada tingkat komunitas di tiap ekosistem lokasi penelitian. Hasil analisis menunjukkan bahwa nilai indeks keseragaman di kawasan perairan Desa Mangunharjo berkisar antara 0,756-0,8244 yang termasuk dalam kriteria nilai mendekati 1, yang berarti tingkat keseragaman tinggi. Menurut Pirzan et al., (2008), semakin besar nilai keseragaman dapat dikatakan merata atau jumlah individu dalam spesies relatif sama, sedangkan keseragaman yang bernilai kecil menggambarkan keseragaman antar spesies di dalam komunitas rendah, yang berarti kekayaan individu yang dimiliki masing-masing spesies sangat jauh berbeda.

${ }^{\odot}$ Copyright by Management of Aquatic Resources (MAQUARES) 
Indeks dominasi (C) digunakan untuk mengetahui ada atau tidaknya spesies tertentu yang mendominasi suatu ekosistem. Nilai indeks dominasi larva ikan yang ada di kawasan perairan Desa Mangunharjo berkisar antara 0,265-0,317 termasuk dalam kriteria nilai mendekati 0 , hal ini berarti tingkat dominasi rendah atau hampir tidak ditemukannya spesies yang mendominasi. Menurut Dhahiyat, et al., (2009), bila dalam suatu struktur komunitas biota yang diamati terdapat spesies yang mendominasi, maka hal ini menunjukkan bahwa kondisi struktur komunitas berada dalam keadaan labil atau sedang terjadi tekanan ekologis. Sedangkan yang terjadi di kawasan perairan pantai, muara, dan mangrove Desa Bedono ini sebaliknya, yaitu tidak ada spesies yang mendominasi.

\section{Keterkaitan Parameter Lingkungan dengan Kelimpahan Larva Ikan}

Pengukuran parameter lingkungan dilakukan disetiap titik pengambilan sampel larva ikan. Hasil yang didapatkan dari pengukuran parameter lingkungan baik fisika maupun kimia, tidak mengalami perbedaan yang signifikan. Nilai korelasi yang didapatkan setelah melalui uji regresi linier berganda menggunakan aplikasi spss versi 20, dengan persamaan $\mathrm{Y}=\mathrm{a}+\mathrm{bX}_{1}+\mathrm{bX}_{2}+\mathrm{bX}_{3}+\mathrm{bX}_{4}+\mathrm{bX}_{5}+\mathrm{bX}_{6}+\mathrm{bX}_{7}$ yaitu 0,604. Menurut Razak (1991) dalam Mutaqin et al., (2014) koefisien korelasi (R) dengan angka 0,604 masuk kedalam kategori hubungan sedang yang dapat diartikan hubungan parameter lingkungan dengan kelimpahan larva ikan berhubungan sedang. Nilai determinasi (Adjusted $\mathrm{R}^{2}$ ) sebesar 0,131 yang menunjukan sebesar 13,1\% kelimpahan larva ikan dipengaruhi oleh parameter lingkungan sisanya, 86,9\% dipengaruhi oleh faktor lain. Faktor lain yang mempengaruhi kelimpahan larva ikan adalah pasang surut dan predator, menurut Olii (2003), pasang surut merupakan faktor yang paling penting mempengaruhi kehidupan dari larva ikan. Keberadaan dari pasang surut dapat menimbulkan perputaran dari air sehingga terjadi transport secara vertikal dari larva ikan. Dengan tidak adanya perputaran air yang ditimbulkan oleh pasang surut maka larva ikan ditemukan pada kedalaman yang lebih dalam. Selain itu adanya predator dan ketersediaan makanan juga menjadi faktor yang mempengaruhi distribusi dari larva ikan, semakin banyak predator di perairan maka tingkat mortalitas larva ikan semakin tinggi yang akan memberi dampak negatif bagi populasi larva ikan.

\section{KESIMPULAN}

Kesimpulan yang dapat diambil dari penelitian Distribusi dan Kelimpahan Larva Ikan di Kawasan Perairan Desa Mangunharjo Kecamatan Tugu Kota Semarang adalah sebagai berikut:

1. Pola distribusi larva ikan pada ketiga ekosistem berdasarkan analisis indeks morista menyebar secara tidak merata (acak). Jumlah larva ikan yang tertangkap selama penelitian secara keseluruhan berjumlah 1.089 individu, dengan jumlah pembagian pada ekosistem pantai 673 individu, ekosistem muara 188 individu, dan ekosistem mangrove 228 individu. Larva ikan yang teridentifikasi terdiri dari 7 famili yakni Ambassidae, Mugilidae, Chanidae, Engraulidae, Nemipteridae, Gobiidae, dan Apogonidae. Pada ekosistem pantai larva ikan yang paling banyak ditemukan yaitu famili Engraulidae dengan jumlah 324 individu, pada ekosistem muara larva ikan paling banyak ditemukan yaitu famili Chanidae sebanyak 69 individu, dan pada ekosistem mangrove larva ikan yang paling banyak ditemukan yaitu famili Ambassidae sebanyak 93 individu.

2. Perbedaan nilai kelimpahan, dan keanekaragaman di tiap ekosistem (pantai, mangrove, muara) berdasarkan uji Kruskall Wallis adalah terdapat perbedaan nilai yang nyata, sedangkan untuk nilai keanekaragaman tidak terdapat perbedaan nilai yang nyata pada ketiga ekosistem.

3. Keterkaitan parameter lingkungan dengan kelimpahan larva ikan diperoleh nilai koefisien korelasi (R) sebesar 0,604 yang berarti hubungan parameter lingkungan dengan kelimpahan larva ikan dikategorikan berhubungan sedang. Nilai koefisien determinasi (Adjusted $\mathrm{R}^{2}$ ) sebesar 0,131 nilai ini menunjukkan sebesar $13,1 \%$ kelimpahan larva ikan dipengaruhi oleh parameter lingkungan, sisanya sebesar $86,9 \%$ dipengaruhi oleh factor lain yaitu pasang surut dan predator.

\section{UCAPAN TERIMAKASIH}

Ucapan terimakasih ditujukan kepada Prof. Norma Afiati, M.Sc., Ph.D dan Churun A'in, S.Pi, M.Si yang telah memberikan saran dan kritik yang sangat bermanfaat bagi penulis. Kepada semua pihak yang telah membantu sehingga penulis dapat menyelesaikan artikel ini.

\section{DAFTAR PUSTAKA}

Anwar, N. 2008. Karakteristik Fisika Kimia Perairan dan Kaitannya dengan Distribusi serta Kelimpahan Larva Ikan di Teluk Pelabuhan Ratu. Sekolah Pascasarjana, Institut Pertanian Bogor

${ }^{\circledR}$ Copyright by Management of Aquatic Resources (MAQUARES) 
Dahuri, R. 1992. Strategi penelitian estuari di Indonesia. Pros. Loka. Nas. Peny. Prog. Pen. Bio. Kelautan dan Proses Dinam.Pesisir. UNDIP, Semarang.

Dhahiyat, Y., Sinuhaji, dan H. Hamdani. 2003. Struktur Komunitas Ikan Karang di Daerah Transplantasi Karang Pulau Pari Kepulauan Seribu [Community Structure of Coral Reef Fish in the Coral Transplantation Area Pulau Pari Kepulauan Seribu]. Jurnal Ikhtiologi Indonesia. 3 (2):87-94.

Fachrul, M. F. 2007. Metode Sampling Bioekologi. Bumi Aksara. Jakarta

Fatah, A. 2014. Mitigasi Dampak Abrasi Air Laut pada masyarakat Petani Tambak Studi Kasus Budidaya Tanaman Mangrove di Kelurahan Mangunharjo Kecamatan Tugu Semarang. Institute Agama Islam Negeri Walisongo Seamarang. Semarang.

Furchan. 2004. Pengantar Penelitian dalam Pendidikan. Pustaka Pelajar Offset. Yogyakarta.

Hukom, F. D. 1999. Ekostruktur dan distribusi spasial ikan karang (famili Labridae) di perairan Teluk Ambon. Pros. Lok. Pengelolaan dan Iptek Terumbu Karang Indonesia. Jakarta.

Kountur, R. 2003. Metode Penelitian Untuk Penulisan Skripsi dan Tesis. PPM. Jakarta.

Krebs, C. J. 1999. Ecological Method. An Imprint of Addison Wesley Longman, inc, Columbia. 636 p

Leis J.M. dan C. E. Brooke. 2000. The Larvae of Indo-Pacific Coastal Fishes: An Identification Guide to Marine Fish Larvae. Fauna Malesiana; Vol.2. Leiden;Boston;Koln. Brill. 850 p.

Leis J M dan D. S. Rennis. 1983. The Larvae of Indo-Pacific Coral Reef Fishes. New South Wales University Press, Sydney and University of Hawaii Press, Honolulu. 269 p.

Mutaqin, A.S., M.H. Didcy, Hanin, N.R. Kiki, dan K. Yunita. 2014. Ukuran Kemampuan atau Kesesuaian Model Square $\left(\mathrm{R}^{2}\right)$. Makalah Analisi Regresi. STIS, Jakarta Odum E P. 1971. Fundamentals of Ecology. Sounders. Toronto.

Olii, A. H. 2003. Kajian Faktor yang Mempengaruhi Distribusi Ichtthyoplankton (Awal Daur Hidup Ikan). Institut Pertanian Bogor.

Pirzan, A. M. dan P. R. Pong-Masak. 2008. Hubungan Keragaman Fitoplankton dengan Kualitas Air di Pulau Baulung Kabupaten Takalar Sulawesi Selatan. Biodiversitas. Maros: Balai Riset Perikanan Budidaya Air Payau. 9 (3):217-221.

Riswandha, N. S. 2015. Struktur Komunitas Larva Ikan pada Ekosistem Mangrove dengan Umur Vegetasi yang Berbeda di Desa Timbulsloko Demak. Diponegoro Journal of Maquares managemen of Aquatic Recources. 4 (4) : 164-173.

Suryandari, A. 2012. Komposisi, Kelimpahan dan Distribusi Larva Ikan pada Estuaria Pelawangan Timur Segara Anakan, Cilacap. Institut Pertanian Bogor.

Suwignyo, P. 1976. Metode dan Teknik Penelitian Bidang Biologi Perairan. Institut Pertanian Bogor. 53 hlm.

Wilhm, J. L., and T. C. Doris. 1986. Biologycal Parameter for Water Quality. Bio Science: 18.

Yanti, T. S. 2010. Perluasan Uji Kruskal Wallis untuk Data Multivariat. Jurnal Statistika, 10 (1) : 43 - 49. 